\title{
The practice of dance as extracurricular activity is related to higher motivation and physical activity level in students
}

\author{
Allana Freitas da Rosa ${ }^{*}$, Nycolle Martins Reis ${ }^{1}$, Melissa de Carvalho Souza Vieira ${ }^{1}$, \\ Alexandra Folle ${ }^{1}$, Adriana Coutinho de Azevedo Guimarães ${ }^{1}$
}

ORIGINAL ARTICLE

\begin{abstract}
The aim of the current study is to compare motivation, self-concept and physical activity level between students practicing dance as extracurricular activity and those who do not. The total of 200 students (mean age $8 \pm 0.8$ years) divided in two groups participated in the experiment: a) physical education (PE) and b) physical education combined with dance practices (PEDP). Two questionnaires were used, one for the parents (Schooling - Economic stratum) and one for students. The students' questionnaire consisted of a structured interview divided in four parts: a) General information; b) Motivation; c) Self-concept; and d) Physical activity level. Descriptive and inferential statistics were used. Results showed that students in the PEDP group were more motivated by Status $(p=0.049)$ and General Affiliation $(p=0.010)$, whereas $88 \%$ of the students in the PE group showed higher social self-concept $(\mathrm{p}=0.010)$. With respect to physical activity level, $100 \%(p=0.000)$ of students in the PEDP group were active and showed screen time 3.88 hours per day $(p=0.000)$. It was possible concluding that students in the PEDP group showed higher motivation and physical activity level than those in the PE group, who showed better self-concept.

Keywords: physical activity, self-concept, dance, students, motivation.
\end{abstract}

\section{INTRODUCTION}

School is the environment where children and adolescents spend most of the day (Miranda \& Cury, 2010). Thus, physical education classes may help promoting physical activity, developing healthy behaviors (World Health Organization [WHO], 2017) and shortening sedentary time in school (Costa, Silva, George \& Assis, 2017). It is known that children and adolescents should practice at least 60 minutes of moderate to vigorous physical activity per day, as well as that $80 \%$ of Brazilian students do not comply with these recommendations (Instituto Brasileiro de Geografia e Estatística [IBGE], 2016); therefore, assumingly, extracurricular activities such as dance classes may reduce physical education deficiencies at school, as well as increase the physical activity level of these students in order to help them adopting a healthier lifestyle (Lakes et al., 2016; Schubert, Januário, Casonatto, \& Sonoo, 2016; Cain et al., 2015).
Motivation is what makes people move; it results from an active, intentional and objectivedriven process, and depends on intrinsic (free will) and extrinsic factors (external factors) (Abreu, Pereira \& Kessler, 2008). Accordingly, teachers should investigate and apply strategies to encourage their students (Jackson-Kersey \& Spray, 2016) to spend more time with sports practicing during extra-class periods by motivating them in physical education classes (Jimínez Castuera, Moreno Navarrete, Leyton Roman \& Claver Rabaz, 2015).

Students who meet the physical education class goals, and perceive them as beneficial, are more likely to develop positive self-concept (Beasley \& Garn, 2013), which consists of the individuals' awareness of their own cognitive, affective and behavioral aspects (Sisto; Martinelli, 2004a). Thus, school plays a key role in students' lives when it comes to self-concept, physical activity and active behaviors outside school.

\footnotetext{
Manuscript received at July 11 ${ }^{\text {th }} 2017$; Accepted at January $9^{\text {th }} 2018$

${ }^{1}$ Universidade do Estado de Santa Catarina, Florianópolis, Brasil.

* Corresponding author: Rua Pascoal Simone, 358 - Coqueiros, Florianópolis - SC, 88080-350, Brasil

E-mail: allanarosa@gmail.com
} 
(Casas, García, Guillamón, García-Cantó, Sotoa, López \& Marcos, 2016; Beasley \& Garn, 2013).

Finally, it is worth highlighting that although dancing is a compulsory physical education practice in elementary education (Ministério da Educação [MEC], 2017), it becomes a ludic positive and pleasurable extracurricular activity alternative (Sousa \& Caramaschi, 2011). Therefore, the aim of the current study was to compare motivation, self-concept, and physical activity level between students who practice dance as extracurricular activity and those who do not. It is worth highlighting that dance practice addition to the school program may favor distinct aspects of students' health.

\section{METHOD}

The current study followed a descriptive crosssectional design, which aimed at observing, recording and analyzing the phenomenon by assessing the participants at once without influencing reality (Thomas, Nelson \& Silverman, 2012).

\section{Participants}

The current study comprised 200 students (mean age $8 \pm 0.8$ years) divided in two groups: a) students participating in 'physical education' (PE) classes, only; and b) students participating in 'physical education combined with dance practices' (PEDP) as extracurricular activity. Physical education classes were compulsory and offered three times a week for 45 minutes, whereas dance classes were promoted at school (as optional extracurricular activity) based on two projects that addressed different modalities such as Ballet, Hip Hop and Jazz. Inclusion criteria were, students in the age group 7-11 years enrolled from the $1^{\text {st }}$ to the $5^{\text {th }}$ grade of an elementary school linked to the largest public school in Santa Catarina State. Students participating in extracurricular activity other than dance classes were excluded from the study in order help exclusively understanding the effect from dancing practiced along with physical education on the assessed variables.

Initially, 1045 students enrolled in the morning and afternoon school shifts were selected (Figure 1). However, 405 students were excluded because they also participated in other extracurricular activities such as soccer, gymnastics, wrestling, among others; 187 were excluded for not belonging to the age group 7-11 years; and 12 were excluded for not being able to understand the questions in the questionnaire. The remaining 441 students were selected to participate in the study and received the terms of consent to be delivered to their parents and / or legal guardians. However, 241 of them did not bring the questionnaires back; therefore, they were excluded from the study. Thus, the final sample comprised 200 students (150 in the PE group, and 50 in the PEDP group).

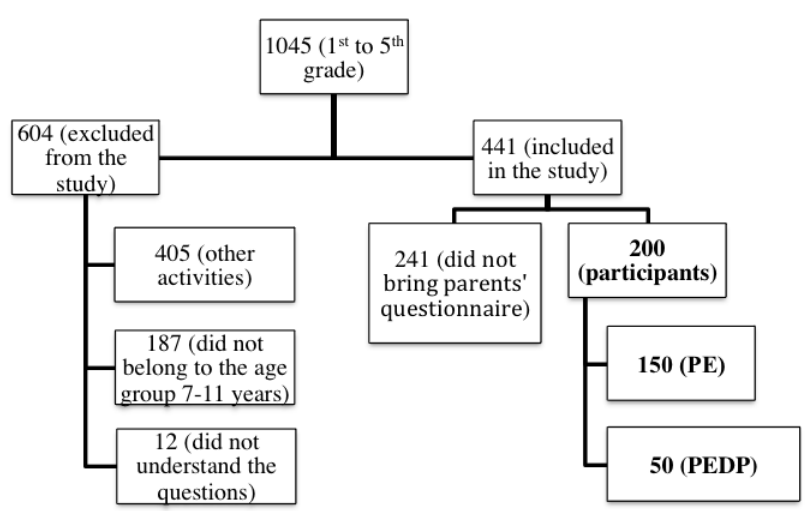

Figure 1. Study participants' selection.

\section{Procedures}

Competition Two questionnaires validated for the herein studied population were used in the experiment (ABEP, 2015; Serpa, 1992; Sisto \& Martinelli, 2004a; Silva \& Malina, 2000). The first one was a self-administered questionnaire sent to the parents and/or legal guardians, which was composed of two parts, namely: a) Schooling (Elementary, High or Higher Education; complete or incomplete) and b) Economic stratum (Class A, B, C, D and E) (ABEP, 2015).

The second questionnaire consisted of a structured interview with the students; it was divided in four parts described below:

a) General information: age, schooling, dance class practiced (or not) as extracurricular activity; anthropometric measurements - such as body mass and height - were collected by researchers through the Plenna Ice Digital Scale. The 2-meter Stadiometer (Compacto) was used to calculate students' body mass index (BMI); they were 
classified as normal, overweight and obese, according to age and gender (WHO, 2015).

b) Motivation: the Sports Activity Motivation Questionnaire (QMAD - Questionário de Motivação para Atividades Desportivas) was used to identify the reasons for young people to practice sports (Serpa, 1992). The instrument comprises 30 questions, which were classified by Fonseca and Maia (2001) according to eight different domains, namely: 1) Status, 2) Emotions, 3) Pleasure, 4) Competition, 5) Physical Shape, 6) Technical Competency, 7) General Affiliation, and 8) Specific Affiliation. Assessment categories were set through an increasing intensity scale consisting of five points: <0.99, not important at all; 1.00-1.99, little important; 2.00-2.99, important; 3.00-3.99, very important; and 4.00-5.00, extremely important (Serpa \& Frias, 1990).

C) Self-concept: The Self-concept Scale for Children and Adolescents (EAC-IJ - Escala de Autoconceito Infanto Juvenil) is used to assess self-concept within personal, family, school and social contexts (Sisto \& Martinelli, 2004b). The instrument comprises 20 questions, 5 about personal and school-related self-concept, 5 on family self-concept and, 6 concerning social selfconcept. Each question may score up to 2 points; the final score of each self-concept subscale is classified as low (lower than or equal to $25 \%$ ), moderate (lower than or equal to $50 \%$ ) or high (higher than 50\%), according to the questions.

D) Physical Activity Level: The Physical Activity Questionnaire for Children (PAQ-C) was used to classify the physical activity level of children and adolescents during the last 7 days previous to the experiment application. The questionnaire comprises 13 questions related to physical activity practices during the school period and leisure times, compared physical activity level, compared physical shape level and to daily mean screen time (Crocker, Bayley, Faulkner, Kowalsky \& McGrath, 1997). Each question is scored from 1 to 5 points to allow classifying individuals from very sedentary to very active. The final result is expressed as the mean of the questions; thus, individuals can be classified as active $(>2)$ or sedentary $(<2)$, after the final result is recorded.

\section{Statistical analysis}

Data analysis was developed in the statistical software IBM - SPSS (version 20.0); descriptive statistics was used to obtain general information, as well as to characterize the sample, and the following inferential tests were conducted: Chisquare and Fisher's exact tests were used to characterize the sample, self-concept and physical activity practice; independent $\mathrm{T}$-test was used to analyze students' motivation and screen time after the normality test (Kolmogorov Smirnov). The herein adopted significance level was $5 \%$.

\section{RESULTS}

There was high prevalence of female students $(71.6 \%)$ enrolled in the $3^{\text {rd }}$ grade of elementary school (34.5\%) who showed normal weight status $(63 \%)$ and belonged to economic class C (64.5\%); there was significant difference in gender $(\mathrm{p}=0.000)$ and school grade $(\mathrm{p}=0.027)$ between groups (data not shown).

Table 1 compares the dimensions of students' sport activity motivation per group and shows significant difference in status $(\mathrm{p}=0.049)$ and general affiliation $(\mathrm{p}=0.010)$. Students belonging to the PEDP group were more motivated by status (wining, feeling important) and general affiliation (being with friends) than students belonging to the PE group.

Table 1

Comparison between students' sports practice motivation dimensions according to the group. Florianópolis, 2017

\begin{tabular}{lccc}
\hline & $\begin{array}{c}\text { PE }(\mathrm{N}= \\
\end{array}$ & $\begin{array}{c}\text { PEDP }(\mathrm{N} \\
=50)\end{array}$ \\
\cline { 2 - 4 } & $\mathrm{M} \pm \mathrm{SD}$ & $\mathrm{M} \pm \mathrm{SD}$ & $\begin{array}{c}\mathrm{p}- \\
\text { value }\end{array}$ \\
\hline Status & $3.12 \pm 0.82$ & $3.39 \pm 0.79$ & 0.049 \\
Emotions & $3.24 \pm 0.99$ & $3.11 \pm 0.80$ & 0.428 \\
Pleasure & $3.73 \pm 0.95$ & $3.84 \pm 0.66$ & 0.438 \\
Competition & $3.39 \pm 1.10$ & $3.62 \pm 1.00$ & 0.201 \\
Physical shape & $3.70 \pm 0.80$ & $3.90 \pm 0.65$ & 0.114 \\
Technical competency & $3.81 \pm 0.82$ & $3.97 \pm 0.73$ & 0.212 \\
General affiliation & $3.72 \pm 0.87$ & $4.07 \pm 0.64$ & 0.010 \\
Specific affiliation & $3.60 \pm 0.93$ & $3.82 \pm 0.84$ & 0.137 \\
\hline Note. PE $=$ Physical Education; & PEDP $=$ & Physical Education \\
combined with dance practices; $\mathrm{N}=$ number of students; $\mathrm{M}=$ \\
mean; SD = standard deviation; T Test (p < 0.05$).$
\end{tabular}

According to Table 2, $52.7 \%$ of students in the PE group presented high personal self-concept scores. The PEDP group presented higher school 
self-concept percentage but was classified at moderate level $(46 \%)$, although there was no significant difference between groups. The family and social self-concepts recorded the highest scores; the PE group stood out, since $88.7 \%$ of its students showed high family self-concept levels and $88 \%$ of them presented high social selfconcept levels. There was significant difference in social self-concept, only, between the PE and PEDP groups $(\mathrm{p}=0.010)$.

Table 2

Self-concept score per group. Florianópolis, 2017

\begin{tabular}{|c|c|c|c|c|c|c|}
\hline \multicolumn{2}{|c|}{ Self-concept per group } & \multicolumn{2}{|c|}{$\begin{array}{c}P E \\
(N=150)\end{array}$} & \multicolumn{2}{|c|}{$\begin{array}{c}\text { PEDP } \\
(\mathrm{N}=50)\end{array}$} & \multirow[b]{2}{*}{ p-value } \\
\hline & & $\mathrm{N}$ & $\%$ & $\mathrm{~N}$ & $\%$ & \\
\hline \multirow[t]{3}{*}{ Personal } & Low & 16 & 10.7 & 4 & 8.0 & \multirow{3}{*}{$0.280^{* *}$} \\
\hline & Moderate & 55 & 36.7 & 25 & 50.0 & \\
\hline & High & 79 & 52.7 & 21 & 42.0 & \\
\hline \multirow[t]{3}{*}{ School } & Low & 32 & 21.3 & 9 & 18.0 & \multirow{3}{*}{$0.793^{*}$} \\
\hline & Moderate & 61 & 40.7 & 23 & 46.0 & \\
\hline & High & 57 & 38.0 & 18 & 36.0 & \\
\hline \multirow[t]{3}{*}{ Family } & Low & 4 & 2.7 & 2 & 4.0 & \multirow{3}{*}{$0.448^{* *}$} \\
\hline & Moderate & 13 & 8.7 & 7 & 14.0 & \\
\hline & High & 133 & 88.7 & 41 & 82.0 & \\
\hline \multirow[t]{3}{*}{ Social } & Low & 3 & 2.0 & 5 & 10.0 & \multirow{3}{*}{$0.010^{* *}$} \\
\hline & Moderate & 15 & 10.0 & 9 & 18.0 & \\
\hline & High & 132 & 88.0 & 36 & 72.0 & \\
\hline
\end{tabular}

Note. $\mathrm{PE}=$ Physical Education; $\mathrm{PEDP}=$ Physical Education combined with dance practices; $\mathrm{N}=$ number of students; $\%=$ frequency; ${ }^{*}$ Chi-Square Test. ${ }^{* *}$ Fisher's exact test. $(\mathrm{p}<0.05)$.

Table 3 shows the prevalence of active students in both groups. All (100\%) students in the PEDP group were active; however, the rate of active students decreased to $79.3 \%$ in the PE group, which was a significant result $(\mathrm{p}=0.000)$. The physical activity level was compared between students and evidenced significant result $(\mathrm{p}=$
0.000): $55 \%$ of the students in the PE group perceived themselves as equally active.

Student screen time was also assessed; the mean screen time in the PE group was higher (5.12 hours/day) than that in the PEDP group (3.88 hours/day); $(\mathrm{p}=0.000$ ) (data not shown).

Table 3

Physical Activity Level compared physical shape and physical activity levels per group. Florianópolis, 2017

\begin{tabular}{|c|c|c|c|c|c|c|}
\hline & & \multicolumn{2}{|c|}{$\begin{array}{c}\text { PE } \\
(\mathrm{N}=150)\end{array}$} & \multicolumn{2}{|c|}{$\begin{array}{c}\text { PEDP } \\
(\mathrm{N}=50)\end{array}$} & \multirow[b]{2}{*}{ p-value } \\
\hline & & $\mathrm{N}$ & $\%$ & $\mathrm{~N}$ & $\%$ & \\
\hline \multirow{2}{*}{$\begin{array}{l}\text { Physical Activity } \\
\text { Level }\end{array}$} & Sedentary & 31 & 20.7 & - & - & \multirow{2}{*}{$0.000^{* *}$} \\
\hline & Active & 119 & 79.3 & 50 & 100.0 & \\
\hline \multirow{3}{*}{$\begin{array}{l}\text { Compared physical } \\
\text { activity level }\end{array}$} & Less active & 40 & 26.7 & 12 & 24.0 & \multirow{3}{*}{$0.000^{*}$} \\
\hline & Equally active & 83 & 55.3 & 15 & 30.0 & \\
\hline & More active & 27 & 18.0 & 23 & 46.0 & \\
\hline \multirow{3}{*}{$\begin{array}{l}\text { Compared physical } \\
\text { shape level }\end{array}$} & Out of shape & 11 & 7.3 & 4 & 8.0 & \multirow{3}{*}{$0.488^{* *}$} \\
\hline & More fit & 110 & 73.3 & 40 & 80.0 & \\
\hline & Less fit & 29 & 19.3 & 6 & 12.0 & \\
\hline
\end{tabular}

Note. $\mathrm{PE}=$ Physical Education; $\mathrm{PEDP}=$ Physical Education combined with dance practices; $\mathrm{N}=$ number of students; $\%=$ frequency; ${ }^{*}$ Chi-Square Test. ${ }^{* *}$ Fisher's exact test. $(\mathrm{p}<0.05)$.

\section{DISCUSSION}

The aim of the present study was to compare motivation, self-concept and physical activity level between students attending to dance classes as extracurricular activity and those who did not. Results showed that students belonging to the
PEDP group were more motivated to perform sports activities and showed higher physical activity level than students belonging to the PE group, who, in turn, showed higher self-concept.

Dance practicing stands out among other activities because it allows children and 
adolescents to freely express themselves, to get to know themselves and the world, as well as to communicate through their bodies (Macovei, Zahiu, \& Sulea, 2014; Candela, Conte, Pastena, D`Anna, \& Paloma, 2013). Thus, students belonging to the PEDP group presented higher sports activity motivation than students belonging to the PE group in the current study. Significant difference was found in dimensions such as status and general affiliation.

Reasons such as "winning", "excuse to leave home", "doing something I am good at", "feeling important" and "being known" are part of the status composing one of the motivation dimensions (Fonseca \& Maia, 2001). Thus, it appears that the aforementioned reasons encouraged students belonging to the PEDP group to get involved in physical and sports activities. However, it is consensus in the literature that sports activity motivation is associated with different variables such as population, age, education level and gender (Martins, Honório, Cardoso, \& Duarte, 2014; Januário, Colaço, Rosado, Ferreira \& Gil, 2012). Therefore, different results were found in studies conducted with 12-21-year-old students attending dance classes (Shibukawa, Guimarães, Machado \& Soares, 2011) and with students practicing sports activities (Martins et al., 2014) who did not consider the status-related reasons as the most important ones.

The present study also recorded significant results for general affiliation, which was considered an important dimension to sports activity practices by students belonging to the PEDP group. According to Fonseca and Maia (2001), general affiliation presents reasons such as "being with friends", "belonging to a group" and "making new friends". Other studies conducted with students who practice dancing pointed out that social interaction and fun are reasons to practice this modality in class-free times (Lakes et al., 2016; Shibukawa et al., 2011; Abreu et al., 2008). Thus, friendship and cooperation encourage students, even those who practice other modalities, to seek in sports the same playful and social character (Oliveira et al., 2017) found in dance (Macovei et al., 2014;
Candela et al., 2013; Shibukawa et al., 2011; Abreu et al., 2008).

Physical education at school encompasses motor, cognitive, affective and social development of children and adolescents (Cunha, Poblacion, Colugnati, Taddei \& Bracco, 2016). The current study found significant social selfconcept results in students belonging to the PE group. Thus, assumingly, students who practice physical education have good intellectual perception of themselves, feel superior to their peers, and want to help others or to seek help when they need it (Sisto \& Martineli, 2004a). According to Abreu et al. (2008), some students who attend dance classes need to be complimented and socially acknowledged in order to keep on dancing. Thus, these students concern about other people's opinion and it can make them loose their good perception about themselves in relation to others; consequently, they may show lower social self-concept level.

All self-concept subscales (personal, school, family and social) showed higher frequency of moderate or high scores in both herein analyzed groups. Accordingly, Cunha et al. (2016) pointed out that 7-11-year-old students had very good perception about themselves, since they presented high scores on personal, school, family and social self-concept. In light of the present study, and of the study conducted by Cunha et al. (2016), it is possible assuming that students belonging to the age group 7-11 years show good self-perception, as well as that the aging factor has negative influence on self-concept perception (Serassuel Junior, Cavazzotto, Paludo, Zambrin \& Simões, 2015). Therefore, it is possible stating that dance practicing may have the strongest influence on the self-concept of students belonging to groups composed of older children, since there is evidence in the literature that dance practicing improves this variable (Draugelis, Martin, Garn, 2014; Ferreira, Vilella, \& Carvalho, 2010).

The analysis applied to the physical activity level of students participating in the present study showed that most of them were active and presented sufficient physical activity levels for their age group. There was significant difference between groups; the PEDP group stood out for 
having $100 \%$ active students in comparison to the PE group. Similar results were presented by Silva et al. (2016), who found $71.7 \%$ prevalence of physically active students. In addition, students who knew the physical activity program available in the school showed even higher physical activity levels. Thus, assumingly, physical activities carried out during the class-free times during the school shift tend to positively influence students' physical activity level (Cain et al., 2016; Edwards et al., 2016; Hubbard et al., 2016).

The compared physical activity level (comparison between the activity of students belonging to the same gender and age group) was also significant between groups. The PE group, which showed $79.3 \%$ active students, presented the best results, since most of the students in this group considered themselves more active than their peers. On the other hand, students showing low physical activity levels considered themselves less active than their peers (Silva \& Malina, 2000). Therefore, it is possible saying that students showed good perception about their physical activity level, if one takes into consideration that the social context influences students' perception and physical activity habits.

According to Langer, Crain, Senso, Levy and Sherwood (2014), if a particular practice increases students' physical activity level, it may also decrease their screen time. For example, physically active students may spend less time performing sedentary activities such as watching TV. According to the herein presented results, students belonging to the PE group showed screen time 5.12 hours/day, on average, in comparison to students belonging to the PEDP group, who showed shorter screen time (3.88 hours/day, on average). Other studies conducted with students belonging to the same age group also found mean screen time longer than 2 hours (Langer et al., 2014; Vasconsellos, Anjos, \& Vasconsellos, 2013). Since watching television and using electronic devices is a reality in children's lives, physical and sports activity practicing in class-free times during school shift should be adopted to reduce students' screen time, as well as to improve their quality of life.

The comparison between students attending dance classes and those who did not showed that this activity had positive influence on these students' sports activity motivation and physical activity level. In addition, dancing may be used as a valuable tool to improve different health aspects. However, the present study did not classify the dance modality, weekly frequency, or practice time, fact that may be a limiting factor in the current study. Thus, these variables should be taken into consideration in future studies.

\section{CONCLUSION}

Students belonging to the PEDP group showed stronger sports activity motivation (status and general affiliation) and higher physical activity level than students belonging to the PE group. In addition, dance practicing as extracurricular activity was also related to shorter screen time. On the other hand, students belonging to the PE group stood out for their selfconcept, mainly in the social subscale, and showed good self-perception.

Given all the benefits dance practicing provides to students' health, it is worth exploring this practice in physical education classes and as extracurricular activity in order to enable students' physical, psychological and social development through a playful and pleasurable activity. In addition, physical education teachers should be aware of the reasons behind students' motivation to practice physical and sports activities in order to develop methodological approaches able to influence students' practice and permanence in physical education classes, as well as in physical activities in class-free times during school shift.

Acknowledgments:

Nothing to declare.

\section{Conflict of interests:}

Nothing to declare.

\section{Funding:}

Nothing to declare.

\section{REFERENCES}

Abreu, E. V., Pereira, L. T. Z., \& Kessler, E. J. (2008) Timidez e motivação em indivíduos praticantes de 
dança de salão. Revista Conexões, 6, número especial.

Associação Brasileira de Empresas de Pesquisa. (2015) Dados com base no Levantamento Sócio Econômico 2010 - IBOPE. Retrieved on March 18, 2015, from http://www.abep.org/

Beasley, E., \& Garn, A. (2013). An investigation of adolescent girls' global self-concept, physical selfconcept, identi ed regulation, and leisure-time physical activity in physical education. Journal of Teaching in Physical Education, 32, 237-253. https://doi.org/10.1123/jtpe.32.3.237

Cain, K. L., Gavand, K. A., Conway, T. L., Peck, E., Bracy, N. L., Bonilla, E., Rincon, P., \& Sallis, J. F. (2015). Physical Activity in Youth Dance Classes. Pediatrics, 135(6), 1066-1075. https://doi.org/10.1542/peds.2014-2415

Candela M., Conte, R., Pastena, N., D’anna, C. \& Paloma, F. G. (2013). The Role of Dancing in the Educational Process. Procedia - Social and Behavioral Sciences, 106, 3069-3074. http://dx.doi.org/10.1016/j.sbspro.2013.12.354

Casas, A. G., García, P. L. R., Guillamón, A. R., GarcíaCantó, E., Soto, J. J. P., López, P. T., \& Marcos, L. T. (2016). Capacidad aeróbica, estado de peso y autoconcepto en escolares de primaria. Clínica e Investigación en Arteriosclerosis, 28(1), 1-8. https://doi.org/10.1016/j.arteri.2015.10.002

Costa B. G. G., Silva, K. S., George, A. M., \& Assis, M. A. A. (2017). Sedentary behavior during schooltime: Sociodemographic, weight status, physical education class, and school performance correlates in Brazilian schoolchildren. Journal of Science and Medicine in Sport, 20(1), 70-74. https://doi.org/10.1016/j.jsams.2016.06.004

Crocker, P. R., Bailey, D. A., Faulkner, R. A., Kowalski, K. C., \& McGrath, R. (1997). Measuring general levels of physical activity: preliminary evidence for the Physical Activity Questionnaire for Older Children. Medicine and science in sports and exercise, 29, 1344-1349.

Cunha, C. T., Poblacion, A. P., Colugnati, F. A. B., Taddei, J. A. A. C., \& Bracco, M. M. (2016). Effect of an Educational Program on Schoolchildren's Energy Expenditure during Physical Education Classes. MedicalExpress, 3(1), M160104. https://dx.doi.org/10.5935/MedicalExpress.201 6.01 .04

Draugelis, S., Martin, J., \& Garn, A. (2014). Psychosocial Predictors of Well-Being in Collegiate Dancers. The Sport Psychologist, 28(1), 1-9. http://dx.doi.org/10.1123/tsp.2012-0093

Edwards, M. J., May, T., Kesten, J. M., Banfield, K., Bird, E. L., Powell, J. E., Sebire, S. J., Jago, R. (2016). Lessons learnt from the Bristol Girls Dance Project cluster RCT: implications for designing and implementing after-school physical activity interventions. BMJ Open, 6(1). http://dx.doi.org/10.1136/bmjopen-2015010036

Ferreira, S. A., Vilella, W. V., \& Carvalho, R. (2010). Dança na escola: Uma contribuição para a promoção de saúde de crianças e adolescentes. Investigação, 10(2), 55-60.

Fonseca A. M., \& Maia J. A. (2001) Análise factorial confirmatória à versão portuguesa do Participation Motivation Questionnaire. In: Fonseca A. M. A FCDEF-UP e a psicologia do desporto: estudos sobre motivação. Porto: Faculdade de Ciências do Desporto e Educação Física, Universidade do Porto.

Hubbard, K., Economos, C. D., Bakun, P., Boulos, R., Chui, K., Mueller, Smith, K. S., \& Sacheck, J. (2016). Disparities in moderate-to-vigorous physical activity among girls and overweight and obese schoolchildren during school- and out-ofschool time. International Journal of Behavioral Nutrition and Physical Activity, 13(39). https://doi.org/10.1186/s12966-016-0358-x

Instituto Brasileiro de Geografia e Estatística. (2016). Pesquisa nacional de saúde do escolar: 2015 / IBGE, Coordenação de População e Indicadores Sociais. Rio de Janeiro: IBGE. Retrieved on March 10, 2017, from

http://biblioteca.ibge.gov.br/visualizacao/livros/ liv97870.pdf

Jackson-Kersey, R., \& Spray, C. (2016). The effect of perceived psychological need support on motivation in physical education. European Physical Education Review, 22(1), 99-112. https://doi.org/10.1177/1356336X15591341

Januário, N., Colaço, C., Rosado, A., Ferreira, V., \& Gil, R. (2012). Motivação para a Prática Desportiva nos Alunos do Ensino Básico e Secundário: Influência do Género, Idade e Nível de Escolaridade. Motricidade, 8(4), 38-51. https://dx.doi.org/10.6063/motricidade.8(4).15 51

Jiménez Castuera, R., Moreno Navarrete, B., Leyton Román, M., \& Claver Rabaz, F. (2015). Motivación y estadios de cambio para el ejercicio físico en adolescentes. Revista Latinoamericana de Psicología, 47(3), 196-204. https://dx.doi.org/10.1016/j.rlp.2014.11.001

Lakes, K. D., Marvin, S., Rowley, J., Nicolas, M. S., Arastoo, S., Viray, L., Orozco, A., \& Jurnak, F. (2016). Dancer perceptions of the cognitive, social, emotional, and physical benefits of modern styles of partnered dancing. Complementary Therapies in Medicine, 26, 117-122. https://doi.org/10.1016/j.ctim.2016.03.007

Langer, S. L., Crain, A. L., Senso, M. M., Levy, R. L., \& Sherwood N. E. (2014). Predicting Child Physical Activity and Screen Time: Parental Support for Physical Activity and General Parenting Styles. Journal of Pediatric Psychology, 39(6), 633-642. https://doi.org/10.1093/jpepsy/jsu021

Macovei S., Zahiu, M., \& Şulea, R. (2014). Theoretical Arguments for Dance as a Means of Providing Aesthetic Education in Primary School. Procedia Social and Behavioral Sciences, 117, 74-80. http://dx.doi.org/10.1016/j.sbspro.2014.02.181

Martins J., Honório S., Cardoso J., \& Duarte, L. (2014). Students' motivation to practice sports in school 
between 9 to 14 years of basic education. Journal of Physical Education and Sport, 14(4), 459-470. http://dx.doi.org/10.7752/jpes.2014.04070

Ministério da Educação. (2017) Base Nacional Comum Curricular. Brasília: Ministério da Educação. Retrieved on June 01, 2017, from http://basenacionalcomum.mec.gov.br

Miranda, R. M. R., \& Cury, V. E. (2010). Dançar o adolescer: estudo fenomenológico com um grupo de dança de rua em uma escola. Paidéia (Ribeirão Preto), 20(47), 391-400. https://dx.doi.org/10.1590/S0103863X2010000300011

Oliveira, V. M. Silva, T. R., Brasil, M. R., Estevão, B. J., Chumlhak, Z., \& Silva, S. R. (2017). Nível de motivação e coordenação motora em escolares ingressantes em um projeto de futsal. Revista Brasileira de Futsal e Futebol, 9(32), 42-52.

Schubert, A., Januário, R. S. B., Casonatto, J., \& Sonoo, C. N. (2016). Aptidão física relacionada à prática esportiva em crianças e adolescentes. Revista Brasileira de Medicina do Esporte, 22(2), 142-146. https://dx.doi.org/10.1590/1517869220162202103473

Serassuel Junior, H., Cavazzotto, T. G., Paludo, A. C., Zambrin, L. F., \& Simões, A. C. (2015). The impact of obesity on the perception of selfconcept in children and adolescents. Revista Brasileira de Cineantropometria \& Desempenho Humano, 17(2), 165-174. https://dx.doi.org/10.5007/1980$0037.2015 \mathrm{v} 17 \mathrm{n} 2 \mathrm{p} 165$

Serpa, S. (1992). Motivação para a prática desportiva Validação preliminar do Questionário de Motivação para as Actividades Desportivas. In: Sobral, F. \& Marques, A. FACDEX: Desenvolvimento somato-motor e factores de excelência desportiva na população escolar portuguesa. (Orgs). Lisboa: 89-97.

Serpa, S., \& Frias, J. (1990). Estudo da relação professor/aluno em ginástica de representação $e$ manutenção. Lisboa: Faculdade de Motricidade Humana.

Shibukawai, R. M., Guimarães, A. C. A., Machado, Z., \& Soares, A. (2011). Motivos da prática de dança de salão nas aulas de educação física escolar. Revista Brasileira de Educação Física e Esporte, 25(1),
19-26. https://dx.doi.org/10.1590/S180755092011000100003

Silva, L. J., Matsudo, V. K. R., Andrade, D. R., Azevedo, M., Ferrari, G. L. M., Oliveira, L. C., Araújo, T. L., \& Matsudo, S. M. M. (2016). The prevalence of physical activity and its associated effects among students in the São Paulo public school network, Brazil. Ciência \& Saúde Coletiva, 21 (4), 1095-1103. https://dx.doi.org/10.1590/141381232015214.19792015

Silva, R. C. R., \& Malina, R. M. (2000). Nível de atividade física em adolescentes do Município de Niterói, Rio de Janeiro, Brasil. Cadernos de Saúde Pública, 16(4), 1091-1097. https://dx.doi.org/10.1590/S0102311X2000000400027

Sisto, F. F., \& Martinelli, S. C. (2004a). Estudo preliminar para a construção da Escala de Autoconceito Infanto-Juvenil (EAC-IJ). Interação em Psicologia, 8(2). http://dx.doi.org/10.5380/psi.v8i2.3254

Sisto F. F., \& Martinelli S. C. (2004b). Escala de autoconceito infanto-juvenil. São Paulo: Vetor.

Sousa, N. C. P., \& Caramaschi, S. (2011). Contato corporal entre adolescentes através da dança de salão na escola. Motriz: Revista de Educação Física, $17(4)$, 618-629. https://dx.doi.org/10.1590/S198065742011000400006

Thomas, J. R.; Nelson, J. K., \& Silverman, S. J. (2012). Métodos de pesquisa em atividade física. 6. ed. Porto Alegre: Artmed.

Vasconcellos, M. B., Anjos, L. A., \& Vasconcellos, M. T. L. (2013). Estado nutricional e tempo de tela de escolares da Rede Pública de Ensino Fundamental de Niterói, Rio de Janeiro, Brasil. Cadernos de Saúde Pública, 29(4), 713-722. https://dx.doi.org/10.1590/S0102311 X2013000400009

World Health Organization. (2017). Physical activity (2007). Retrieved on March 20, 2017, from http://www.who.int/mediacentre/factsheets/fs3 $85 / \mathrm{en} /$

World Health Organization. (2015). Growth reference 519 years (2007). Retrieved on December 29, 2015, from http://www.who.int/growthref/who2007_bmi_f or_age/en/

All content of Journal Motricidade is licensed under Creative Commons, except when otherwise specified and in content retrieved from other bibliographic sources. 